(- Academy of Management Journal

2013, Vol. 56, No. 1, 113-136.

http://dx.doi.org/10.5465/amj.2010.0778

\title{
REKINDLING THE FLAME: PROCESSES OF IDENTITY RESURRECTION
}

\author{
JENNIFER HOWARD-GRENVILLE \\ University of Oregon
}

\author{
MATTHEW L. METZGER \\ University of Colorado at Colorado Springs
}

\author{
ALAN D. MEYER \\ University of Oregon
}

\begin{abstract}
We build theory on the process of collective identity resurrection through a qualitative study investigating how community members reenergized a valued community identity following years of decline. Our findings suggest a recursive model of identity resurrection, in which community leaders marshal tangible resources such as money and human talent to orchestrate experiences and community members authenticate the experiences by judging them resonant with memories and existing identity symbols. This model draws attention to the role of experience and emotion in identity processes, extending theory that has tended to focus narrowly on cognitive aspects of collective identity. We discuss implications for processes of identity reproduction and resurrection in organizational settings, and for interdependencies between community and organizational identities.
\end{abstract}

When I got back, Apple had forgotten who we were. Remember that "Think Different" ad campaign we ran (featuring great innovators like Einstein, Gandhi). . . . It was certainly for customers, but it was even more for Apple. That ad was to remind us of who our heroes are and who we are. Companies sometimes do forget. Fortunately we woke up.

-Steve Jobs, on returning as Apple's CEO after more than a decade's absence (Jobs, 2004)

The birth of track and field [in this community] . . . was organic and when it died and withered away, bringing it back was going to be difficult.

-Community resident, commenting on the resurrection of Track Town U.S.A.

Collective identities, as expressions of "who we are," can profoundly shape the actions of the mem-

The authors are grateful for the valuable suggestions of guest editor Ann Langley and three anonymous AMJ reviewers. Kathryn Aten, Kim Elsbach, Mary Ann Glynn, Davide Ravasi, Paul Roline, Patricia Thornton, and Dave Whetten offered helpful comments on earlier versions of this article. We gratefully acknowledge the financial support of Pat and Stephanie Kilkenny and the James Warsaw Sports Marketing Center at the University of Oregon's Lundquist College of Business. The authors extend special thanks to Janet and Tom Heinonen, Bill Dellinger, Vin Lananna, and our many other informants in Track Town, U.S.A. bers, prospective members, and outside audiences of an organization. Organizations' identities influence how their members interpret strategic issues, respond to threats, and undertake change or retrenchment (Dutton \& Dukerich, 1991; Fiol, 2002; Gioia, Schultz, \& Corley, 2000; Ravasi \& Schultz, 2006). Regional community identities attract entrepreneurs and firms (Freeman \& Audia, 2006; Romanelli \& Khessina, 2005), shape local norms and social structures that imprint distinctive organizational practices (Chiles, Meyer, \& Hench, 2004; Galaskiewicz, 1997; Marquis, Glynn, \& Davis, 2007), and impart a unique experience of place (Gieryn, 2000; Molotch, Freudenburg, \& Paulsen, 2000). Collective identities are frequently regarded as persistent. Because "a collective identity provides a sense of self and meaning . . . a certain degree of inertia is not only inevitable, but desirable" (Ashforth \& Mael, 1996: 52-53).

But what happens when a collective identity fades? Can it be resurrected? As the opening quotes suggest, both companies and communities suffer identity decline, and some seek to reclaim what was lost. Apple is a notable example, but motorcycle manufacturer Harley Davidson also spent over a decade offering products that were not true to its corporate self before executives rescued it from near "extinction" in 1983 (Fournier \& Lee, 2009: 105). Lego plumbed the depths of its 75-year history, restoring the central idea of play, in its 2004 turnaround (Schultz \& Hernes, 2010). Organiza- 
tional scholars have paid attention to the processes underlying identity change (Corley \& Gioia, 2004; Dutton \& Dukerich, 1991) and more recently have built theory on identity maintenance (Ravasi \& Phillips, 2011) and its periodic regeneration (Birnholtz, Cohen, \& Hoch, 2007; Foreman \& Parent, 2008). Yet identity resurrection following a period of decline remains an undertheorized process. Recent work calls for more attention to how a collective entity responds when it recognizes that "we are not what we used to be" (Ravasi \& Phillips, 2011: 127). By studying the decline and resurgence of a community identity, we build theory on the processes of collective identity resurrection. A regional community offers an "extreme case" for building theory about identity resurrection (Eisenhardt, 1989) because top-down leadership, a key source of continuity and renewal for organizational identities (Whetten, 2006), may be weak or absent in communities (King, Felin, \& Whetten, 2010).

Our study was guided by the research question: How do actors resurrect a collective identity? We focus on the identity of Eugene, Oregon, a community that garnered the label "Track Town U.S.A." while hosting the 1972 U.S. Olympic Track and Field Trials. Eugene was home to a rich history of magnificent track and field performances, a storied coach known as much for starting the country's jogging craze as he was for cofounding Nike, and a spirited young runner, Steve Prefontaine ("Pre”), who simultaneously held every American track record between the distances of 2,000 and 10,000 meters. Community members spoke of how these elements had coalesced into a distinct identity, saying "Track Town" represented "who we are in this community."

Yet by the late 2000s, the moniker Track Town U.S.A. evoked little more than a nostalgic yearning. The local newspaper reported that some "questioned whether Eugene could legitimately still call itself “Track Town U.S.A.”" (McDonald, 2009). Three decades had elapsed since Pre's tragic death in 1975, and the University of Oregon (UO) had not garnered a national track and field title since 1985. The image of Bill Bowerman, UO's legendary coach and Nike's cofounder, was frozen in a bronze statue at Hayward Field-holding a stopwatch in one hand, his foot resting on his wife Barbara's storied waffle iron, which Bill used as the mold to cast the sole for Nike's prototype "Waffle Trainer" running shoe. In 2008, the return of the U.S. Olympic Track and Field Trials to Eugene offered the community a chance to reclaim its identity, although some feared the event would trade cheaply on cherished memories.
To build theory on collective identity resurrection, we gathered data from interviews, observations, and archives that captured historical and contemporary aspects of Eugene's identity as Track Town. In probing the puzzle of resurrection, we discovered that actors' experiences and emotional involvement perpetuate a collective identity and play a central role in its resurrection. Our process model describes how organizational and community leaders orchestrate experiences designed to sustain an identity and how members can authenticate these experiences as resonant with a remembered and symbolized past. By developing our process model over three distinct eras, we explain how leaders' enactment of (or failure to enact) specific processes triggers (or fails to trigger) authenticity, leading to identity decline, threat, or resurrection.

This work makes three main contributions. First, we develop a process model of collective identity resurrection that can apply to both organizations and communities. Resurrection demands leaders who are astutely aware of a symbolized and remembered past and members who have "tended the embers" of that past during the period of decline. Second, we theorize that experience and emotion can be central to identity reproduction and resurrection. Identity has been criticized as a "narrowly cognitive, linguistic . . construct" (Harquail \& Wilcox King, 2010: 1621) that becomes manifest in leaders' claims and members' understandings (Ravasi \& Schultz, 2006; Whetten, 2006). Our analysis suggests that although identity certainly is claimed and understood, it is also is lived and felt. Experience and emotional involvement bring a past identity into the present by activating narratives or symbols, infusing them with meaning for newly recruited members. Experiences and emotions "reload" the symbolic memory bank by adding fresh accounts and new memories that become future identity referents.

Our third contribution is to extend the literature on community influences on organizations and organizing practices, which so far has foregrounded economic (Freeman \& Audia, 2006; Romanelli \& Khessina, 2005) and social structural (Marquis, 2003) explanations. We argue that a place-based configuration of human inhabitants, experienced emotions, sagas, and symbols can coalesce to transform a region into a beloved place steeped in symbolic meanings. Closer attention to this aspect of community identity can yield insight into how interactions between communities and organizations generate and transform meanings (Marquis \& Battilana, 2009). 


\section{COMMUNITIES, IDENTITIES, AND PROCESSES OF CONTINUITY AND CHANGE}

Regional communities are place-based social units that supply the contexts for the firms, voluntary organizations, social movements, and individuals who are located within them. For certain sorts of organizations, a community identity is an innate component of organizational identity. For instance, the organizational identities of city governments, hospitals, and universities are inextricably fused with the identities of their geographic regions. Other organizations opt in voluntarily, recognizing that a regional identity offers unique resources that can be harnessed for organizational purposes (Romanelli \& Khessina, 2005). Despite considerable attention to the influence of community identity on organizational action (Cowen \& Cowen, 2010; Glynn, 2008; Marquis, 2003; Marquis et al., 2007; Romanelli \& Khessina, 2005), little is known about how community identities arise and evolve.

To build theory on identity resurrection at the community level, we borrow from the literature on identity continuity and change in organizations (Corley \& Gioia, 2004; Dutton \& Dukerich, 1991; Fiol, 2002; Gioia et al., 2000; Ravasi \& Schultz, 2006). Because identity conveys both the distinctiveness and coherence of an entity, it is a construct that "travel[s] easily across levels of analysis" (Albert, Ashforth, \& Dutton, 2000: 13). Communities, like organizations, exhibit distinctive characteristics that persist over time (Chiles et al., 2004; Freeman \& Audia, 2006; Marquis \& Battilana, 2009; Molotch et al., 2000). The distinctiveness of communities becomes encoded in labels that characterize clusters of economic activity (Freeman \& Audia, 2006; Romanelli \& Khessina, 2005), localized social norms (Galaskiewicz, 1997; Glynn, 2008; Marquis, 2003; Saxenian, 1996), physical features (Brehm, Eisenhauer, \& Krannich, 2006; Gieryn, 2000), or combinations of these factors (Chiles et al., 2004; Molotch et al., 2000).

In another parallel to organizational identity, residents and indigenous organizations often cast the distinctiveness of a community in a positive light, advancing descriptors such as Branson, Missouri's "All-American wholesomeness" (Chiles et al., 2004) or Atlanta, Georgia's "entrepreneurial and opportunistic spirit” (Glynn, 2008). However, these claims must persuade audiences who assess their fidelity in light of actual community features (Romanelli \& Khessina, 2005: 345). Thus, popular acceptance of a community's identity, much like that of an organization's identity, depends on achieving some fidelity between the claims of community leaders and the beliefs of members and nonmembers (Dutton \& Dukerich, 1991; Hsu \& Hannan, 2005).

Despite these functional similarities between organizational and community identity, which suggest the appropriateness of borrowing theory between levels of analysis (Whetten, Felin, \& King, 2009), questions remain about the extent to which community identities exhibit continuity versus change, and the mechanisms through which actors might influence each trajectory. On one hand, community identity is portrayed as highly persistent and "resistant to purposeful change" (Marquis \& Davis, 2008: 462). Localized social norms (Glynn, 2008), patterns of interorganizational relationships (Galaskiewicz, 1997; Marquis, 2003), and length of residency (Flaherty \& Brown, 2010) all contribute to persistence of a community identity, suggesting that members tend to perpetuate, rather than alter, identities. On the other hand, communities lack "sovereignty" as entities, and their members are "not constrained by strict roles and hierarchical control" (King et al., 2010: 298), suggesting that leaders' actions may be needed to prevent loss of salience of an identity. The organizational identity literature has long considered how members and leaders contribute to identity continuity and change. We use its insights to inform identity resurrection processes at the community level.

\section{THE ROLE OF AGENCY IN IDENTITY CONTINUITY AND CHANGE}

Organizational identity has been regarded as relatively persistent (Ashforth \& Mael, 1996), disrupted and reasserted or revised only when external audiences question an identity (Dutton \& Dukerich, 1991) or leaders seek to reorient it (Corley \& Gioia, 2004; Fiol, 2002). Recent accounts instead assert that organizational identity must be actively maintained (Ravasi \& Phillips, 2011) and portray identity as an ongoing accomplishment arising from leaders' and members' actions (Gioia, Price, Hamilton, \& Thomas, 2010; Ravasi \& Schultz, 2006). Such accounts combine two formerly disparate perspectives on identity. The social actor perspective attributes identity continuity to the persistence of identity claims (Whetten, 2006) often "expressed as institutionalized mission statements, policies, and routines” (King et al., 2010: 295). These claims specify appropriate behavior to members and convey core attributes to external audiences (Whetten \& Mackey, 2002). Leaders, particularly founding leaders, are central to establishing and perpetuating identity claims. The social constructionist perspective asserts that identity is per- 
petuated by identity understandings sustained by members and derived from their everyday organizational experiences (Gioia et al., 2000).

In each perspective, cognitive processes are central to how actors perpetuate identity (Ravasi \& Schultz, 2006). In the social actor perspective, leader-driven "sensegiving," an attempt to shape others' interpretations, is a primary mechanism through which identity claims are established (Whetten \& Mackey, 2002). In the social constructionist perspective, member "sensemaking" underlies the construction of identity understandings (Gioia et al., 2000). Recent empirical work observes that sensegiving and sensemaking can "generate an embedded dynamic" (Ravasi \& Schultz, 2006: 436) that is "mutually recursive and constitutive" (Gioia et al., 2010: 6) when identity claims and understandings coincide, suggesting that identity perpetuation has a "structurational" character (Sewell, 1992).

The cognitive mechanisms of sensegiving and sensemaking can perpetuate an identity, but, as with other structurational processes, may yield outcomes that vary according to exactly how and under what contextual conditions the mechanisms are enacted (Feldman, 2004). Indeed, identity change has also been found to result from leader sensegiving and member sensemaking. Leaders or managers can revamp an organization's identity through claims that attempt to realign it with changes in external expectations (Chreim, 2005), organizational forms (Corley \& Gioia, 2004), or strategic directions (Fiol, 2002; Tripsas, 2009). Although leaders occupy privileged positions as sensegivers, these claims must be "socially validated" by members (Ashforth \& Mael, 1996: 39) who may reject identity claims that are seen as too different from their understandings (Reger, Gustafson, Demarie, \& Mullan, 1994). Alternatively, members may instigate identity change when they reinterpret and even change the labels and meanings associated with an organization's identity (Corley \& Gioia, 2004). However, such potential changes must resonate with externally validated claims to coalesce in broadly shared understandings (Gioia et al., 2010).

\section{RESTARTING IDENTITY PROCESSES}

We focus on a case in which the structurational mechanisms of identity continuity and potential change have broken down. We use the term "identity decline" to describe such a condition. Identity decline occurs when identity claims and understandings gradually lose salience, as a result of not being actively asserted or experienced. This differs from "identity drift," which refers to a form of identity change arising from the gradual misalign- ment of traditional claims with new understandings, beliefs, or practices (Albert \& Whetten, 1995) and which can be addressed by managers selectively revising claims to fit the new understandings (Ravasi \& Phillips, 2011). What mechanisms can reactivate identity-perpetuating processes after decline? Are the cognitive mechanisms of sensegiving and sensemaking sufficient, and, if so, how are they enacted? Studies of episodic or "iterative" organizations-such as summer camps (Birnholtz et al., 2007), sporting contests (e.g., the Olympic Games), or other event-driven organizations (e.g., Academy of Management meetings) - offer clues to this theoretical puzzle (Foreman \& Parent, 2008). In each instance, leaders play a primary role in regenerating an identity. In the case of a summer camp, regeneration is fairly straightforward: identities are typically reenacted by incumbent leaders in the same facilities and geographic location. In other cases, regeneration is harder, as when leaders and members change, venues change, or longer periods of latency elapse (e.g., the Olympic Games). Under such circumstances, creating an identity for each episode calls for a process better designated "recreation" than regeneration.

In other circumstances, such top-down sensegiving efforts may be less warranted or less effective in regenerating an identity because members themselves do not turn over or because artifacts, traditions, or narratives take on enough symbolic importance (Dacin \& Dacin, 2008; Gieryn, 2000; Glynn, 2008) to "provide the raw material for identity formation" (Weber \& Dacin, 2011: 294). In some settings, members of an organization cling to symbols or collective memories in efforts to reclaim a legacy identity (Ravasi \& Schultz, 2006; Schultz \& Hernes, 2010), even in the extreme case, in which the organization no longer exists (Walsh \& Glynn, 2008).

Understanding how community identity is resurrected therefore demands attention to leader and member actions and how these actions reference and recreate aspects of identity that are remembered and symbolized, as well as those that are episodically regenerated. Our analysis led us to a process model that captures the interactions between member and leader actions in resurrecting identity and at the same time augments the predominantly cognitive understanding of each actor's role in processes of identity continuity and change.

\section{METHODS}

\section{Research Setting}

Eugene, Oregon, is well suited to building process theory on the resurrection of a community 
identity. Eugene's identity as Track Town has been widely recognized by outsiders and insiders since the early 1970s, allowing us to collect data covering the lengthy period that preceded resurrection efforts. We designed the research as a longitudinal case study to capture historical dynamics and took a multimethod approach. We conducted in-depth, semistructured interviews with central figures who participated personally in Track Town's rise, fall, and resurrection. Additional primary data were ob- tained through brief structured interviews and through our naturalistic observation of actors, events, and performances during the resurrection period. We supplemented these sources with secondary data providing further insight into the historical development of Track Town's identity, including archived documents, journalistic accounts, and personal memoirs. Multiple data sources enabled "triangulation" of our observations. Data sources and uses are summarized in Table 1.

TABLE 1

Description of Data

\section{Data Types and Dates}

Primary Data

Naturalistic observation

2008 U.S. Olympic Track \& Field Trials, Hayward Field (June 27-July 6)

Spectator attendance at NCAA and USA Track \& Field meets (March 2006-April 2011)

Running in Eugene Marathon and 10K road races (2005-11)

Interviews

24 semistructured interviews, lasting between 45 minutes and two hours (April 4, 2008-November 15, 2010)

366 structured interviews with residents, fans, and athletes (June 25-30, 2008)

$\underline{\text { Secondary Data }}$

UO Athletic Department documents and displays

Records of NCAA-sponsored track and field events (1984-2010)

Historical timeline listing pivotal events and accomplishments (1900-2009)

Newspaper articles

All articles in four newspapers (campus, local, and regional) about collegiate or postcollegiate track and field (January 1991-December 2010)

Bowerman papers

Bill Bowerman's personal papers: correspondence, notes, memoranda (1932-99).

Book-length memoirs

Bowerman and the Men of Oregon

(Moore, 2006)

Out of Nowhere (Hollister, 2008)

Documentary films

Fire on the Track: The Steve

Prefontaine Story (Chambers

Productions, 1995)

Oregon Experience (Oregon Public Broadcasting, 2011)
Eight competition days, many shorter events (Hayward Field)

$25+$ meets (Hayward Field)

Two half-marathons, five 10Ks (Eugene)

211 pages of text (verbatim transcriptions from audiotape)

338 pages of text transcribed from written and audiotaped responses (airport and Fan Festival)

Annual statistics (UO campus)

Hall of Champions (UO campus)

335 articles/sports columns (accessed online)

43 linear feet of archived documents (UO Knight Library)

Two volumes

60-minute video

30-minute video
Insight into Steve Prefontaine's life and accomplishments.

Participant observation during the turning point in resurrection of Eugene's identity as Track Town U.S.A.

Participant observation yielding insight into athlete-fan connection.

Participant observation yielding insight into "lived experience" of running in Track Town.

Insight into actions and beliefs of current and former UO track and field coaches, athletes, Olympic Trials organizers, Oregon Track Club officers, sports journalists, local residents.

Identification of symbolic referents ("carriers") of Track Town identity (people, places, and objects). Interviewees' emotional reactions to the idea of Track Town.

Assess performance of UO track and field athletes over time, assess community/fan interest in terms of meet attendance. Temporal bracketing of eras in Track Town's history.

Determine press coverage and interpretation of track and field over time. Coded to assess frequency of the term "Track Town."

Identify strategies and actions undertaken to promote UO track and field and boost community involvement.

Contextualize data in narrative accounts of Oregon track and field.

Insight into Bill Bowerman's life and accomplishments. 


\section{Data Collection}

In-depth semistructured interviews. Key informants were nominated by university athletic department officials, the local newspaper's sports editor, university archivists, and other expert observers. We recruited 24 informants, several of whom we interviewed in tandem, ${ }^{1}$ and two of whom we interviewed on two occasions. Our informants included current and former UO track coaches, former athletes, local sports reporters, officers of the Oregon Track Club (a voluntary organization that supports amateur and professional runners and local events), historians, track meet organizers, and representatives of the county's visitors bureau. We conducted and audiotaped semistructured face-to-face interviews with these informants, each lasting between 45 minutes and two hours. We asked all informants to reflect and comment on the meaning of "Track Town," the origins of the phrase, and the key events and actors linked with it and also asked them to identify symbols they associated with the Track Town identity. We asked them to relate how and why Eugene's identity as Track Town changed over time, what events or forces they regarded as responsible for changes, and for specific comments on whether and how the identity was regenerating. Other questions were tailored to each informant's specific role. When transcribed, these interviews comprised 211 pages of singlespaced text.

Brief structured interviews. We developed a brief structured interview instrument to assess how residents, fans, and athletes understood and articulated the Track Town identity. We trained undergraduate students to conduct and audiotape these interviews. During the 2008 Olympic Trials, we dispatched our student interviewers to the local airport and to the site of a "Fan Festival" held adjacent to the event venue (Hayward Field). We worked alongside the students to survey 366 informants. Interviewers obtained demographic information and ascertained whether an informant was an athlete, an avid track fan, or a casual spectator. They then asked informants if they had heard the term "Track Town" and to describe what it meant to them. Next, informants were handed printed lists enumerating specific people, places, and things said to symbolize Eugene's identity as Track Town. For each list, informants were asked to rank-

\footnotetext{
${ }^{1}$ We interviewed two married couples together, and two other pairs of individuals who collaborated in organizing the Olympic Trials or other major events. Not only was it convenient to interview them together, but we gained valuable information as each was able to feed off the other's insights, elaborate, and clarify details.
}

order items' centrality to the idea of Track Town and to reflect and elaborate upon the basis of their rankings. These interviews typically lasted between five and ten minutes. We entered informants' rankings into a spreadsheet for analysis and transcribed the audiorecordings of their remarks.

Naturalistic observation. We worked as volunteers at the 2008 Olympic Trials and attended over 25 other track meets sponsored in Eugene by NCAA or USA Track \& Field. ${ }^{2}$ We ourselves trained on city trails and streets and ran in local road races. We attended and audiorecorded lectures, panel discussions, and a Bach Festival concert premiering music composed in honor of Coach Bill Bowerman. We visited historically significant sites including Hayward Field, Pre's Trail (a bark running trail whose construction was championed by Steve Prefontaine), and Pre's Rock (the site of the auto crash in which he died) and took photographs. These activities let us engage dozens of track fans in conversation, observe how athletes and visitors interacted with sites and physical artifacts (e.g., placing mementos at Pre's Rock), and observe interactions between athletes and community members (e.g., at panel discussions).

Archival data. We obtained extensive documentary data from collections maintained by the UO library, the UO Athletic Department, and the Oregon Track Club. These sources yielded memoirs, correspondence, and personal records of former coaches and administrators, newspaper clippings and articles from sports magazines, membership and governance records maintained by the Oregon Track Club, and selected audio and visual recordings. We obtained program booklets distributed at signature track meets, read nonfiction literary accounts, and viewed and selectively transcribed dialogue from filmed documentaries.

\section{Data Analysis}

We analyzed our data in line with the customary approach to building grounded theory (Glaser \& Strauss, 1967), as elaborated by Langley (1999), to include sensemaking strategies termed "grounding," "organizing," and "replicating." Grounded theory techniques were invoked first, to induce key themes, events, and symbols that seemed to adhere to and explicate the Track Town identity. As Lan-

\footnotetext{
${ }^{2}$ The National Collegiate Athletic Association (NCAA) organizes the athletic programs of most of the major colleges and universities in the United States. USA Track \& Field is the national governing body for the sport of track and field.
} 
gley (1999) and Meyer (1991) recommended, we developed visual maps to theoretically frame and organize our data. We met regularly to discuss and assimilate embryonic ideas and to compare ideas emerging from our data with constructs in the identity literature. Throughout this process, we returned to the archives and to the field to gather additional data that could corroborate or elaborate our emerging lines of sight. The concept of authenticity surfaced early in our analyses, for it featured prominently in informants' accounts of Eugene's track and field history, in their explanations for the decline of the Track Town identity, and in the hopes and fears they expressed about Track Town's resurrection. However, it was initially unclear exactly what role authenticity played in the community's identity processes. Another early observation was the unexpected frequency and depth of emotional content in informants' responses to our factual questions. Accordingly, we noted the analytical promise of the twin constructs of emotion and authenticity, holding onto our hunch that they were significant (Locke, Golden-Biddle, \& Feldman, 2008) while continuing to work back and forth between these and other emerging constructs and our various data sets.

We deepened our understanding of the emergence of the Track Town identity and its essence by creating graphic and tabular displays to reduce data. All three authors studied transcripts of the semistructured interviews, adding potential codes in the margins. This process generated over 100 emergent codes, which, through discussion, we condensed to those that captured critical aspects of actors, causal relationships between actors and events, and potential mechanisms underlying identity creation, decline, and resurrection. To facilitate formal coding and focus primarily on mechanisms, we further refined our list of codes, distilling out a set of 33. Interview data and selected archival materials $^{3}$ were imported into the qualitative data analysis program Atlas.ti. These data were coded by two authors, with the third reviewing them for reliability.

Coding alerted us to the importance of specific identity referents and to the classes of actors that referenced, connected, or produced such referents.

\footnotetext{
${ }^{3}$ The sheer quantity of and formats of some of the archival data made it unrealistic to include all secondary sources in the Atlas.ti file. For example, Bowerman's records were stored in hard copies retrievable only via the help of an archivist at the UO library. We perused these files and, with the assistance of a student researcher, photocopied select sources, and summarized information from others in an Excel spreadsheet.
}

Following Glynn (2008), we initially used Scott's (2003) term "carriers" as a sensitizing concept to refer to symbols, ideas, events, and people that appeared to help the identity "move from place to place and time to time" (Scott, 2003: 879). Scott distinguishes carriers of four types-symbolic systems, relational systems, routines, and artifacts (2003). Whereas the term "carriers" connotes largely inanimate receptacles for identity content and referents, our developing understanding of the resurrection process led us to regard identity as propelled by both tangible and intangible resources that agents draw into use, and by experiences that regenerate identity-relevant understandings and emotions. Intangible resources in our analysis include symbols and relational systems (defined as "connections between actors, including both individual and collective actors" [Scott, 2003: 886]) that are tapped and regenerated through experiences. Tangible resources (financial, human, and physical) also fuel the generation of experiences, which in turn attract further tangible resources.

We noted the centrality of particular groups and individuals to the resurrection of the Track Town identity and saw that different sorts of individuals leveraged different kinds of resources in crafting various experiences. In particular, we noted the role of organizational and community leaders in marshaling tangible resources and the role of community members as guardians of intangible resources. Whereas earlier work has suggested that members often play the role of identity change agents, we observed that certain community members actively and tenaciously conserved and protected the identity. Following Dacin and Dacin (2008: 330), whose work on tradition applies the term "custodians" to those who are "exemplars or practitioners of a given tradition," we coined the term identity custodian to refer to an actor who focuses attention, invests time, and exerts energy in an effort to sustain a collective identity.

As we continued to work iteratively between our data and the identity literature, we converged upon a process model that depicts how key actors (leaders and identity custodians) perpetuate or resurrect a community identity by drawing on tangible and intangible resources and generating orchestrated and ongoing experiences that authentically reproduce a symbolized and remembered identity. We performed a final round of coding to alter, merge, and elaborate earlier codes as we developed this model. We returned to our data to examine how the various mechanisms in our model had been enacted at different stages in Track Town's history, allowing us to link these enactments to the identity outcomes of decline, threat, and resurrection. To 
set the stage for a full delineation of our model, we now relate the essence of the Track Town identity.

\section{THE DECLINE AND RESURRECTION OF TRACK TOWN}

As noted earlier, by the early 1970s the city of Eugene had witnessed legendary athletic performances and was home to a storied coach, Bill Bowerman, and an accomplished and charismatic young runner, Steve Prefontaine. However, Track Town's unique character transcended any specific individual or performance. Track Town's distinctiveness was forged by two processes: (1) community engagement in the sport, as reflected in the relational system that connected the city's elites, residents, fans, and athletes, and (2) a sustained pattern of events that cultivated a unique track and field experience in Eugene and elicited a spirited emotional response from residents, fans, and athletes.

A powerful bond connected Eugene's residents to the sport of track and field, with community members deeply engaged as fans, volunteers, and even as participants. This bond had been forged early in the tenure of Bill Bowerman, who, according to one interviewee, was revered for winning, but "was more known for his . . . ability to motivate and unify [the] community." Bowerman's abiding influences on the community's relational systems include the formation of the Oregon Track Club, "All-Comers Meets," and jogging clinics open to the public.

In the 1950s, Bowerman helped found the Oregon Track Club (OTC), a volunteer organization that organized, publicized, and officiated locally held track meets. One interviewee noted that OTC offered more than just a means to coordinate volunteers for Bowerman; rather, it was "his way to bring in people from the community and get them on board. Find the movers and shakers. Find the people with the bucks." Others remarked that the OTC offered Bowerman a way to co-opt the community's social elite, noting that Bowerman would "have the vice president of the bank as the starter, with the mayor and his son holding the [finish line] tape."

Bowerman also created opportunities for community members to attend Hayward Field, the university's track and field stadium, to compete in weekly meets, the All-Comers Meets, and to learn about and engage in the newfangled practice of jogging. One resident who moved to Eugene in the 1970s recalled that competing at the All-Comers Meets became "just a part of the local fabric" and that the jogging clinics were so successful and unprecedented in the U.S. that the magazine Life sent a photographer to document this "bizarre" phenomenon (Moore, 2006). Bowerman used Hayward
Field to anchor all of these events, insisting that it "be a community facility and not just a UO facility, open to the public for use."

As a result of these actions, Eugene's residents became renowned for their knowledge of track and field and emotional connection to the sport. One former coach noted, "From the time I first got here, it was clear that the people in the stands understood the sport. . . . They knew what a good mile time was and what a good half-mile time was." The connection went beyond a cognitive one. As a former UO runner put it, "It's 11 or 12 thousand people who absolutely understand. It's not an academic understanding, it's an emotional understanding. It's joining in and screaming [athletes] on to goodness." One interviewee noted that the confluence of this community-wide education and enthusiasm created a "self-fulfilling prophecy that [athletes] expected to be treated well here" and as that reputation grew, more athletes came to perform.

By the time Steve Prefontaine, arrived at UO in 1969, the community was primed to be captivated by his brash, no-holds-barred running style and athletic accomplishments, which included seven NCAA titles and numerous American records. An athlete recalled:

It was a very spiritual experience to watch Pre run. That's why he packed the stands in Eugene and everywhere else. [People would] watch Pre run and they'd go away feeling better about themselves. . . . He showed each of us the best that's within all of us.

Another recalled how he would "watch the crowd somehow get energized by [Pre]" and said, "When he'd race . . . you kind of ran with him. It was an incredible feeling." The 1972 U.S. Track and Field Olympic Trials showcased Eugene's passion for Pre and the sport of track and field to the rest of the country, captivating outsiders and giving them a glimpse of the relational fabric and experiences that underpinned the identity. An interviewee observed:

The 1972 Trials were ... the perfect storm in a way. Bowerman was the Olympic Coach and [his] athletes were very well represented in the Trials. Eugene had been a jogging center for probably ten years by that time, so Bowerman had created the crowd. . . . The newspaper covered it as I have never seen the sport covered before. People went away talking about Eugene being Track Town.

Building on this momentum, the community continued to attract both large-scale events (the Olympic Trials returned in 1976 and 1980) and individual athletes (who moved to Eugene to live and train). Thus, it initially seems hard to understand the decline that subsequently set in. Although much of the 
literature on community identity calls attention to durable social structures and norms or persistent understandings of a community's distinctive features, the circumstances surrounding Eugene's identity decline suggest that these accounts might underestimate the need for identities to be periodically, or even continuously, refueled.

\section{A PROCESS MODEL OF IDENTITY REPRODUCTION}

Our process model discloses how community identity is reproduced through the actions of specific types of actors. We first discuss the more general process of identity reproduction before showing how the model and processes are altered through specific enactments, enabling resurrection or other outcomes. At its core, our model captures the interactions between tangible and intangible resources and lived experiences; identity inheres in and is propelled by these interactions. As shown in Figure 1, stocks of tangible resources (top of figure) are marshaled by organizational and community leaders ${ }^{4}$ to produce "orchestrated experiences." In

\footnotetext{
${ }^{4}$ We use the term "leaders" to refer to those in formal organizational or community roles that enable their incumbents to access and organize tangible resources. In an organizational setting and in the identity literature these individuals might be termed "managers." In each case, we recognize that such individuals also draw on and manipu-
}

our case, orchestrated experiences include track and field events that may be locally organized by community or university leaders, or larger events that require these parties to coordinate with external organizations (e.g., USA Track and Field, the US Olympic Committee). Through their roles in formal organizations (e.g., the UO, Nike, event management companies), leaders access tangible financial resources (money needed to bid on and stage events), human resources (skilled athletes and ardent volunteers), and physical resources (Hayward Field and other infrastructure). As shown in the figure's central boxes, these orchestrated experiences offer opportunities for identity reproduction by showcasing athletic performances and eliciting emotional responses from fans and spectators. Responses to these orchestrated experiences, however, rely also on other experiences that enable observers to interpret their meanings, imbue them with significance, and ultimately regenerate the intangible symbolic and relational resources that propel the identity forward in time.

As shown in the lower portion of the figure, a "pool" of intangible resources includes symbolic resources (stories, media accounts, statues, and memorials) and relational systems (connections between custodians, residents, fans, and athletes) that

late symbolic resources, and we note the effectiveness of specific leaders in these roles as we discuss our findings.

FIGURE 1

Process Model of Identity Reproduction

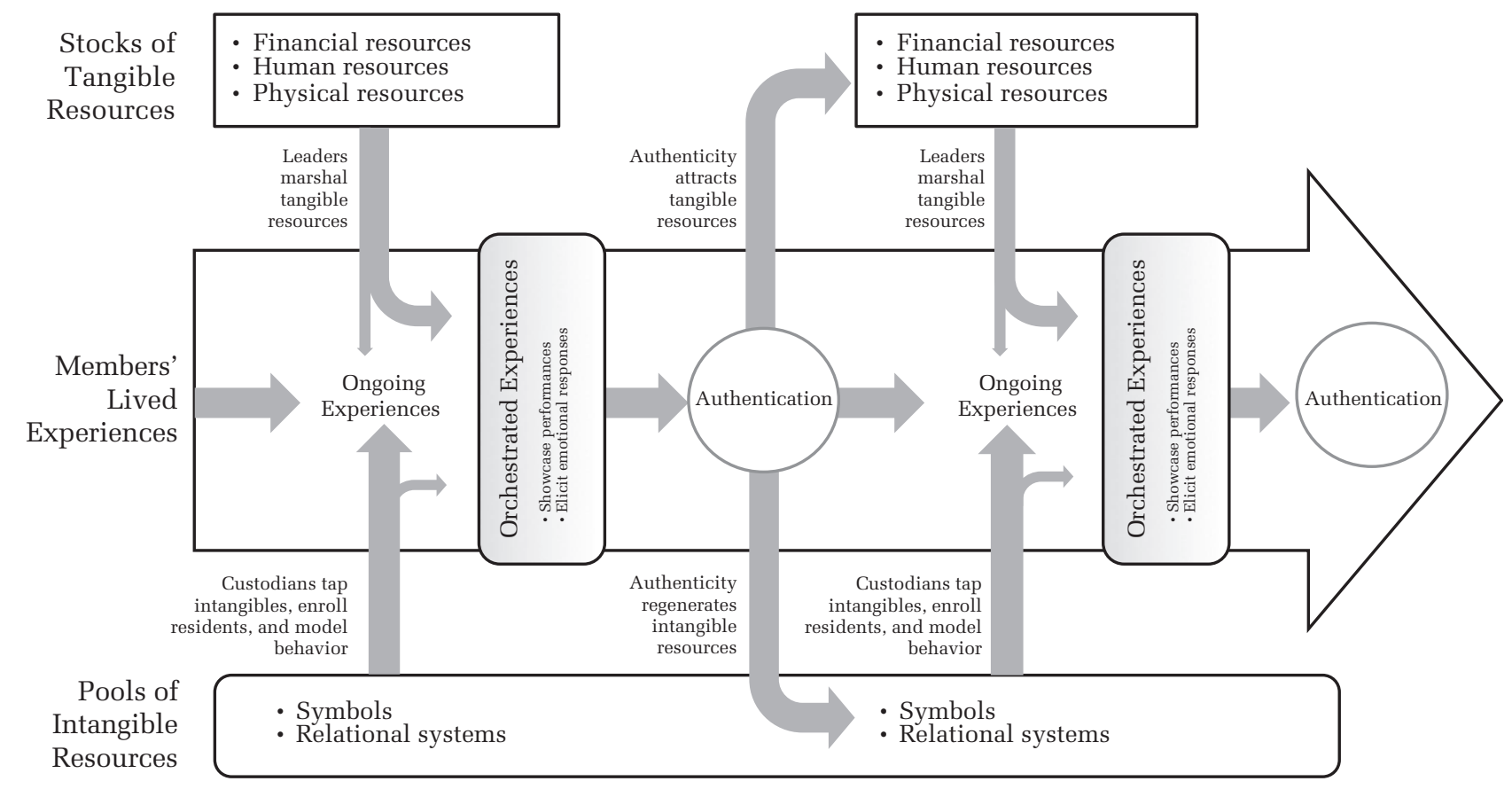


capture past expressions of the identity. To reproduce an identity, both identity custodians and leaders use these resources. Custodians leverage them in two particularly important ways. First, custodians tap symbols and relational systems as they effectuate "ongoing experiences," (see the broad arrow running through the middle of the figure). Ongoing experiences are differentiated from orchestrated experiences because they are produced from the bottom up, typically by volunteers, require no formal external sanction, and occur more frequently and repetitively. Such experiences enroll members who may only weakly identify with the collective identity and deepen their investment in it. Second, identity custodians tap symbols and activate and build relational systems when they model behavior during orchestrated experiences. In our case, identity custodians, through their roles as spectators or volunteers at events, helped residents learn how to be Track Town fans-for instance, when and how to clap rhythmically as an athlete runs down the long jump track, or how to check the wind speed meter before celebrating the establishment of a new record. Such participatory experiences prime residents and new fans to respond appropriately, cognitively and emotionally, to performances at orchestrated experiences. In this way, just as Bowerman had "created the crowd" when the Track Town identity was forming, custodians helped reproduce the identity by modeling behavior and, through this, rewove a relational system that connected residents, fans, and athletes. Astute leaders can also tap the intangible resources that carry the traces of a past identity, as we discuss below in distinguishing identity resurrection from identity reproduction.

A final, but crucial process for identity reproduction is authentication, represented as a circle in Figure 1. Custodians, fans, and residents who are steeped in the identity through their prior participation authenticate (or fail to authenticate) the content and emotional tenor of orchestrated experiences. Authentication checks for and affirms resonance between a remembered, symbolized identity and present experiences. Authentication is lived and felt, rather than calculated and analyzed, and it occurs during, not after, participation in experiences. The words of an interviewee arriving at the Eugene airport days before the '08 Trials captured this, as he puzzled over the importance of various people, places, and things to Eugene's Track Town identity and concluded, with tears welling in his eyes, that:

There's something else I'd sure like to figure out, and I'm sure you would like to figure out too, [which is] why is it that the citizens of this town . . . get goose bumps [sitting at Hayward Field]. Because that's what Track Town is-Track Town is the roar of fans as much as it is any of that other stuff. I don't know [why], but it is.

Similarly, a UO archivist reflected on how, shortly after moving to Eugene, she had puzzled over the large number of people who came in looking for material on track and field. Only after she attended a major track meet (upon the urging of a student researcher) did she feel she "got it," explaining, "I now think I understand it . . . [attending a meet] is not exactly a religious experience, but close to it." It is the shared emotional response to an orchestrated experience, not simply shared attendance, that deepens residents' and fans' understanding of symbols, bringing the past into the present ("This must be what it felt like to watch Pre run!”).

At the same time, authentication regenerates intangible symbolic resources by reloading the pool with new stories, images, records, or memories. Authentication rejuvenates relational systems, as residents who began as casual spectators become fans, and it forges fresh ties as up-and-coming athletes connect personally with fans, residents, and custodians. These regenerating mechanisms (depicted by the arrow leading from authentication to the lower box in Figure 1) propel current identityrelevant experiences into the future by embedding them in reinvigorated symbols and relationships. Finally, authentication also enables leaders to attract the tangible resources (new athletic talent, money, and sponsorship) needed to stage future orchestrated experiences (as depicted in the arrow leading from authentication to the upper box in Figure 1).

To portray the recurring nature of these processes and the central role of authentication as a "stage gate" between cycles, Figure 1 depicts two cycles progressing over time. The regeneration of resources creates new opportunities for leaders to marshal tangible resources and opportunities for custodians as well as leaders to tap intangible resources in staging orchestrated and ongoing experiences. Both sets of actors-and both types of experiences-are crucial to the model, since left untended, resources do not endure or automatically trigger experiences and emotional responses.

Next, to illustrate the dynamics of our process model, we map it onto three distinct eras, punctuated by UO coaching changes, that accompanied the waning and waxing of Track Town's identity. The University of Oregon was recognized by interviewees as being "at the core" of the organizations 
that were critical to the Track Town identity, with the UO track and field coach serving as the pivotal leader. Under three coaches, the identity declined, was undermined in a way that blocked its reproduction, and finally was resurrected.

\section{IDENTITY INERTIA AND ITS LIMITS: DELLINGER ERA}

Shortly after the '72 Olympic Trials cemented Eugene's identity as Track Town, two events abruptly drained much of the momentum. Bill Bowerman unexpectedly retired from his coaching role in 1973 to devote his efforts towards the funding and construction of UO facility improvements. Three years later, hours after his 38th race at Hayward Field, Steve Prefontaine died in a single-car accident, just blocks from the UO campus. The energy each had infused into Track Town lasted for a time under new coach Bill Dellinger, a former UO runner and Bowerman's assistant coach. But by 1998, 25 years after Dellinger took over as coach, the consensus was that to call Eugene Track Town was to drift into nostalgia. As one interviewee said, "We just weren't making it happen ... through the late 1980s and all the way through the 1990s ... we were not the track capital of the world."
By the end of Dellinger's long career, the identity was no longer being adequately refueled through injections of tangible resources, resulting in hollow orchestrated experiences that elicited diminished emotional responses. As the relational system withered, symbols of the identity were not renewed, and tangible resources grew harder to attract. For simplicity, we depict the Dellinger era as a single cycle of the model, but a more complete analysis would track multiple cycles showing these mechanisms reinforcing each other over time. We represent the end result in Figure 2 as a reduction in tangible resources (depicted by the shrinking size of this box) and a depletion of symbols and relational systems (depicted by the downward slope in the line representing the level in the pool of intangible resources).

\section{Marshaling Tangible Resources, Orchestrating Experiences, and Eliciting Emotions}

Early in his coaching career, Dellinger continued marshaling tangible resources by tapping into the vestigial Track Town identity, as sustained by Bill Bowerman's continuing involvement in the community. Bowerman spearheaded Eugene's successful bid for the 1976 Trials, carrying on the hosting

FIGURE 2

Identity Decline, Threat, and Resurrection ${ }^{\mathrm{a}}$

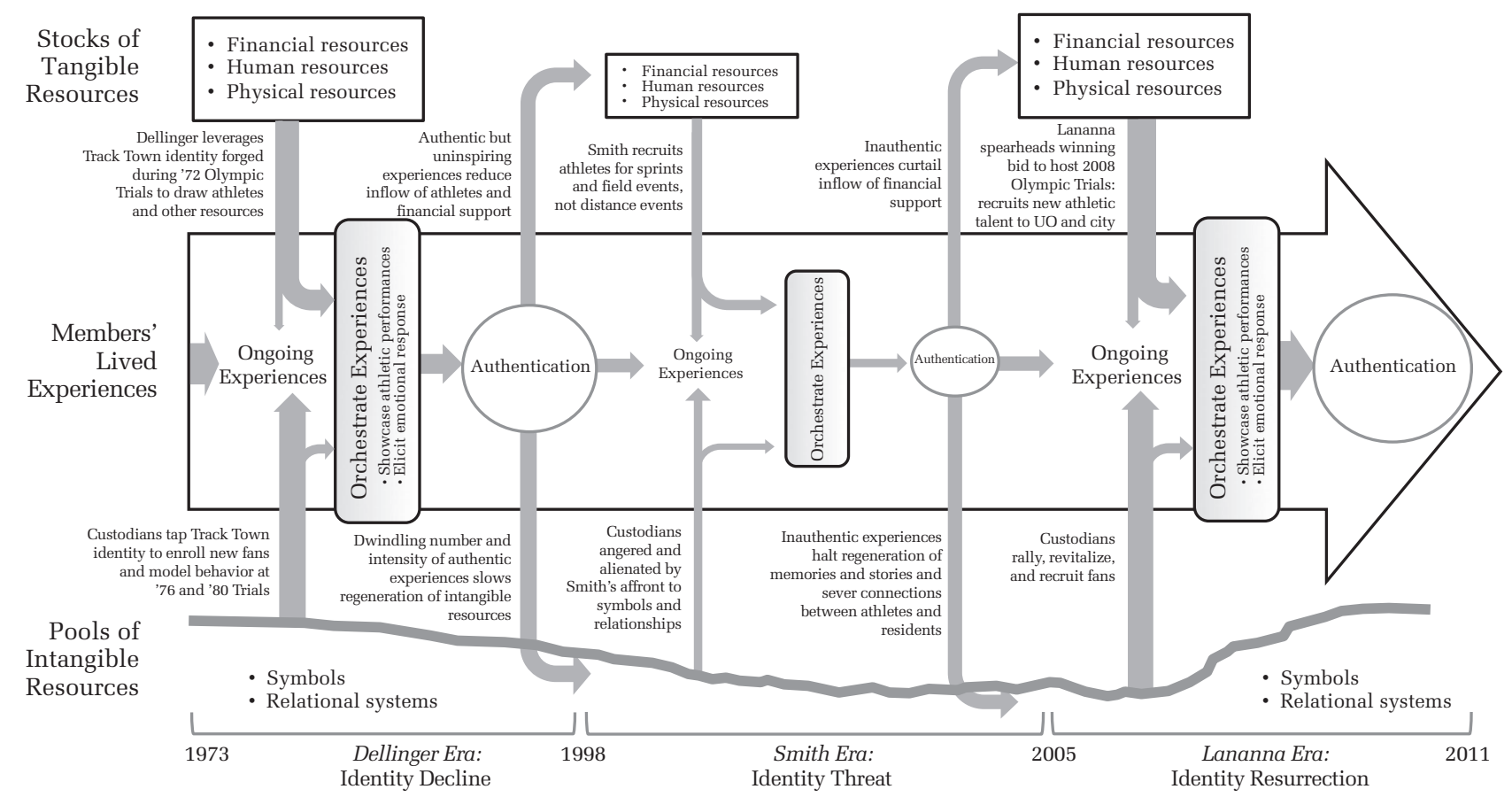

${ }^{a}$ The sizes of boxes, circles, and fonts reflect the quantities of tangible resources; orchestrated experiences' success in showcasing athletic performances and eliciting emotional responses, and the extent of authentication generated. The width of arrows in the figure depicts flows of resources, and the thick horizontal line near the bottom of the figure depicts the changing depth of pools of intangible resources. 
of track's premiere orchestrated experience. Pre's legacy endured and continued to attract athletes to train at UO. One remarked, "I still wanted to go. I knew that [Dellinger] was still there and so I felt if he had brought Pre to that level then maybe he could help bring me to my full potential." Similarly, Eugene continued to lure postcollegiate athletes, with one interviewee noting that the concentration of these athletes "peaked in the early 80 's [with about] 60 Olympians training . . . for the 1984 Olympics." These tangible resources bolstered Dellinger's and other community leaders' orchestration of the 1976 and 1980 Olympic Trials.

The staging of the 1980 Trials, however, marked a turning point. In part, this resulted from the U.S. boycott of 1980 Moscow Olympics, an event beyond the community's control. One interviewee noted that even though Eugene residents "tried to do the right thing" and turned out in force for the "Trials to Nowhere," the feel of the event was "kind of hollow" because everyone knew the winners could not compete in the actual Olympic Games. The 1980 Trials were by and large judged as authentic by veteran fans, but this was more by default than design. One noted, "Dellinger took it for granted that this is the way it was. There was never any great effort to promote [Track Town as an identity]. [He felt] it's always been that way in Eugene and it was always going to be that way." Dellinger maintained Bowerman's practice of recruiting middle distance runners and showcasing them locally, but the quality of the UO teams began to decline. The former women's coach put it bluntly: "We were crummy, all through the '90s." Figure 3 (bottom) shows a significant dip in the women's team performance during that time, and a similar but shorter-lived dip in that of the men's team, based on placement in the PAC-10 meet, an annual tencollege conference championship. ${ }^{5}$

\section{Failure to Attract New Tangible Resources}

The degraded emotional responses to orchestrated events slowed the inflow of tangible resources that Dellinger and other community leaders could leverage. One interviewee observed that beginning in the mid 1980s, "There was a steady decline" in resident postcollegiate athletes as runners started to train elsewhere. Dellinger's ability to marshal resources was curtailed further by NCAA

\footnotetext{
${ }^{5}$ Athletic department administrators at the UO consider the team's performance in the Pacific-10 Conference (Pac-10) to be the most accurate gauge of the program's overall success from year to year.
}

regulatory changes that transformed Hayward Field into an outdated track, diminishing the value of this physical resource with a stroke of the pen. One interviewee explained, "It wasn't a championship track anymore," because the new rules had rendered it too "skinny and narrow" to host sanctioned events. Another noted, "It was fine in 1980, but by 1987 it was unusable." The solution was to widen the track by moving back the distinctive covered wooden grandstand that ran its length. Interviewees recalled the laborious grassroots effort needed to raise money to move the grandstand, as by then UO athletic department, community, and major donor interest had waned.

\section{Tapping While Failing to Regenerate Intangible Resources}

The decline in tangible resources was accompanied by a depletion of intangible resources. Early in Dellinger's era, the relational system and symbols remained robust. One interviewee reflected that "Dellinger, really because he was a nice guy, automatically connected to the community, and because he worked with Bowerman, by association, it . . . carried over." However, even Dellinger acknowledged the difficulty of living up to his predecessor, noting shortly after his hiring, "There is no way for me to ever be Bill Bowerman. I can only be Bill Dellinger carrying on the lessons and legacy of Bowerman” (Moore, 2006: 309). Others observed that Dellinger was less able than his predecessor to tap and sustain the relational system that connected community residents to his athletes and the sport. One said, "I love him as an individual but ... Dellinger wasn't the same sort of promoter and community guru that Bill Bowerman was-so the momentum started running down towards the end of Bill Dellinger's career."

Critically, other identity custodians responded to this eroding leadership and the diminished quality of orchestrated experiences by curtailing their own efforts to perpetuate the Track Town identity. One former UO runner recalled that it grew hard to model behavior and enroll others in the identity: "We didn't hold many events and when we did, no one showed up for them. I mean, even I had to drag myself to [meets] because there was no energy." Generational turnover magnified this attrition. One long-time track and field supporter recalled feeling that "time was running out" to engage the next generation in Track Town's identity, explaining that "if a hard-core track fan like me has to drag himself to Hayward Field . . . why would my kids be interested in going?" Not surprisingly, the ensuing generation failed to assume leadership posi- 
FIGURE 3

Hayward Field Attendance and University of Oregon's Placement in the Pacific-10 Conference's Track and Field Championship Meet ${ }^{\mathrm{a}}$
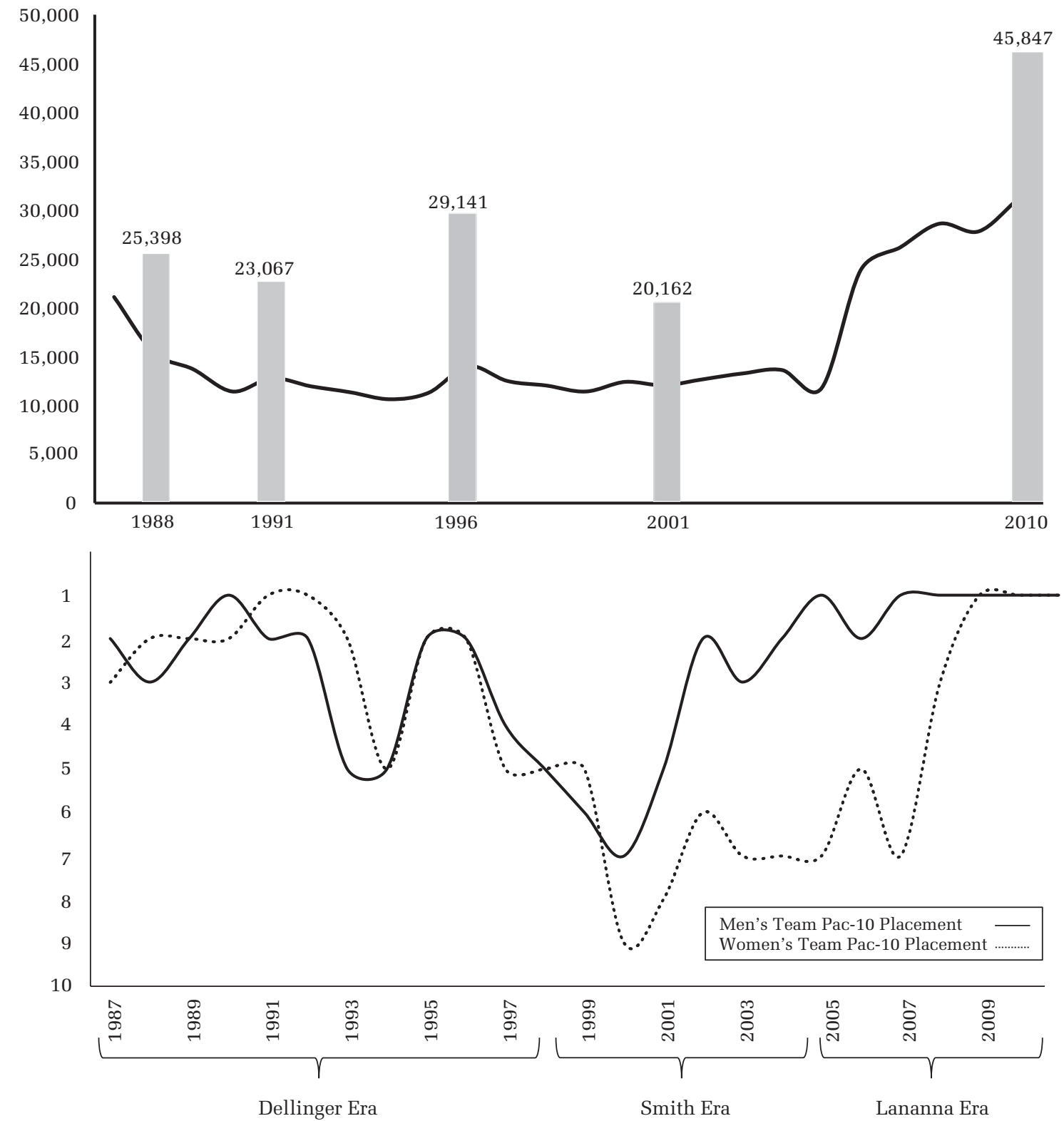

\footnotetext{
a The solid line combines the attendance figures of four annual track and field events at Hayward Field (missing attendance figures were interpolated from the years immediately before and after the omission). The gray bars represent the attendance for NCAA Outdoor Track and Field Championships held at Hayward Field during the period that data were available for the annual events.
}

tions in organizations such as the Oregon Track Club that had become so central to producing ongoing experiences by tapping past symbols and relational systems. Many interviewees spoke of the UO runners from the 70s and 80s as the "lost generation," that "just went away instead of being right in the middle of things, as you'd expect they would." One noted that in the latter years of Dellinger's career, "there just wasn't a high-powered organization with people interested in track and field."
By the late 1990s, Track Town's demise seemed all but assured. Still, interviewees spoke of the "embers" that continued to be tended and fanned during this period by certain custodians. Several pointed to the "Pre Classic," an annual track meet that continued to bring world-class athletes to Eugene and gave credit to its local organizer for orchestrating experiences that "help[ed] us hold on to what we had ... so we were reminded every year how great it was." Other custodians worked tire- 
lessly to protect important symbols of the identity; one interviewee recalled "jogathons" and other efforts that volunteers mounted to raise money and awareness to protect Hayward Field from deterioration and to relocate its iconic east grandstand. Many nonresidents clung to Eugene's identity as Track Town as well. A visitor center staff member recalled:

While [residents] were feeling disconnected from that legacy, the people who [visited] here-people who really are into track and field-the flames never died out for those folks. So we would get questions about Pre's Rock and people would go to Hayward Field and run on the track .... . A frequent question at our visitor center was how to get to those iconic places.

In summary, the Dellinger era illustrates the gradual "running down" of a collective identity when it is not actively tended by leaders or custodians. In the words of one interviewee, the decline “wasn’t obvious, it just sort of happened." In 1998, Bill Dellinger's retirement brought a new coach to the position, and the UO teams' performances began to improve considerably (see the bottom of Figure 3). However, as we elaborate next, this was not enough to reenergize the identity.

\section{IDENTITY THREAT AND THE TRIGGERING OF RESURRECTION: SMITH ERA}

The centrality of experience and emotion to the Track Town identity is perhaps best illustrated by events that began unfolding in 1998. The actions of the new track coach, Martin Smith, sent the already anemic process of marshaling tangible resources into a tailspin and shattered the authenticity of participants' experiences. More serious were actions that tarnished the symbols and weakened the relational system that Track Town's identity drew upon. Together, the breakdown of these leaderdriven and custodian-stewarded processes elicited a backlash that turned into a groundswell. Figure 2 represents the breakdown of the mechanisms of marshaling tangible and tapping intangible resources as shrunken arrows, leading to experiences that were not authentic, and severing the mechanisms of attracting tangible and regenerating intangible resources, all but halting the reproduction of the identity. We refer to this period as one of identity threat, because it called into question members' beliefs about central and distinctive aspects of their identity (Elsbach \& Kramer, 1996; Ravasi \& Schultz, 2006). Often identity threats are depicted as episodic and originating from outside the collective, but our case illustrates that the threat may build slowly and endogenously. Eventually, such a threat can trigger member and custodian-driven resurrection efforts.

\section{Marshaling Illegitimate Tangible Resources and Orchestrating Inauthentic Experiences}

As we noted, Coach Smith rebuilt a competitive UO team that delivered significantly improved results, but he did so by adding strength in sprinting and field events, while moving the team away from its traditional emphasis on middle distance running. Since team standings in meets are determined by summing the points obtained by individual placements in all track and field events, there were several ways to be successful. An interviewee recalled how the UO team won the PAC-10 title in 2004 by "scoring all of the points around distance [i.e., in nondistance events], but not much in distance." He and others observed that the new coach "was determined that he was going to have a successful team but he went at it his way, and his way wasn't the traditional Oregon way." Athletic talent was central to producing orchestrated experiences, but Eugene residents and fans had come to expect a certain kind of talent. One interviewee reflected on this time and said that the UO team has to have some "superstars" and "a certain percentage of those have to be middle or long distance runners ... this community wants distance runners."

Having already recruited unaccustomed athletic talent, instead of tapping the value embedded in Hayward Field, Smith proceeded to squander this resource in orchestrating disappointing experiences for community members. One interviewee observed that the coach's philosophy was to "save his athletes for the big meets ... so it ended up that they didn't run in Eugene." This attenuated the relational system that connected residents to athletes. "People in town didn't have the same connection, they didn't know who the athletes were," observed one long-time resident, adding "take Jason Hartmann, for instance, who was an All American several times in cross country and track. He could walk down the street and go totally unrecognized!"

Failure to marshal tangible resources and orchestrate experiences that the community had come to expect elicited lackluster emotional responses that often caused residents and fans to judge those athletic performances they did see as inauthentic. An interviewee said:

When you went to one of those meets ... you might see a 5000 meter race run with nobody from UO in it ... and that just seemed like heresy after Bowerman and the era of Dellinger where you would see a dozen yellow shirts [UO colors].

Another interviewee suggested that Smith was the "exact opposite" of Bowerman "so even though [Coach Smith] had good team performances there 
was no community response." The coach's decisions about the team's profile and his views about saving their peak performances "didn't sit well," with identity custodians, who, according to an interviewee "said 'No, that's not the Oregon way to be successful.",

\section{Tapping Intangible Resources without Enrolling Residents}

As noted previously, custodians continued to create ongoing experiences through events such as the All-Comers Meets and other volunteer-driven efforts. However, Smith's action thwarted their efforts to tap and regenerate intangible resources. One interviewee said "I've been told . . . that [Smith] would say 'don't bring up the name Prefontaine' ... he tried to create his own history instead of building upon the wonderful history that was already here." More seriously crippled were custodians' efforts to enroll residents and new fans in the Track Town ethos and to model behaviors at orchestrated events. The lack of connection between athletes and residents and the lack of energy at the track meets were partly to blame, but the coach's decision to limit community access to Hayward Field's running track shredded the relational system and halted enrollment of new residents in the identity. One interviewee commented that "putting a padlock on Hayward" created a rift between the community and the track team, recalling how Bowerman had always insisted on keeping the field available for public use and noting "most of the years that I've been in Eugene . . . 25 now, Hayward Field has been open to the public." Hayward Field symbolized not only the athletes and performances it had been home to, but also the personal connections residents felt to the sport. One long-time resident observed, "Hayward Field . . . is the Fenway Park or Wrigley Field of Track. But one of the things that makes Hayward Field magic is that we can run there." He continued:

Some of my best memories don't have anything to the do with the stadium being full or somebody setting a record, it's some of the runs I take at 6 o'clock in the morning . . I I take my token lap at Hayward Field ... [and] go by and slap Bill Bowerman's hand on his statue, just to thank him for all he did.

The groundswell of reaction from custodians and community members that occurred under Smith suggests that a collective identity, even one that had been running on memory and nostalgia, can become more sharply defined and fervently defended when the intangible resources upon which it rests are threatened. One interviewee said:
We could have been satisfied with winning [under Smith]. He won some PAC-10 Championships, [but] it just wasn't the right formula for this community. This community had a mandate, whether it knew it or not, for something bigger.

Identity custodians who had previously acquiesced to the decline were galvanized to action. One former UO runner recalled asking his contemporaries from the "lost generation" whether they could allow "track and field at the University of Oregon to continue to slip off into obscurity?" The answer, "a resounding no!" spurred them to action. In 2005, Smith was ousted as coach and Vin Lananna hired as his successor. Although insiders were circumspect about exactly how this happened, it clearly resulted from the withdrawal of financial and other support by the UO's leaders and boosters. One noted, "People in Eugene, people in high places, the alumni and financial supporters expected more."

In summary, the Smith era illustrates the breakdown of leader actions that produce identity-resonant experiences. After failing to marshal tangible resources essential to delivering experiences that electrified the community and sustained its identity, the leader disparaged the intangible resources that encapsulated past, cherished expressions of the identity. As a result, custodians and community members dismissed orchestrated experiences as inauthentic, halting the regeneration of both tangible and intangible resources.

\section{IDENTITY RESURRECTION: LANANNA ERA}

The hiring of Coach Lananna in 2005 began rekindling the Track Town identity. The final cycle of Figure 2 strongly resembles the more generalized model in Figure 1, but the enactment of three mechanisms were particularly important for resurrection. First, the focal leader envisioned and orchestrated an experience that was bigger and bolder than any of his predecessors had envisioned, projecting a captivating tableau to the community's demoralized identity custodians and track fans. Second, this leader astutely created a series of smaller-scale orchestrated experiences that showcased memorable athletic performances, brought forward symbols from the past, and engaged the community in ways reminiscent of Track Town's heyday. Resurrection of an identity is facilitated when leaders marshal tangible resources while simultaneously tapping intangible ones that activate the symbolic and relational essence of the atrophied identity. In powerfully tapping intangible resources, leaders can be seen as stepping beyond 
their organizational roles to also act as identity custodians. The third enabling mechanism for resurrection was the fanning of the declining identity's embers by faithful custodians with deep roots in the community.

\section{Marshaling Tangible Resources and Orchestrating Experiences}

Lananna proved to be adept at marshaling financial, physical, and athletic resources to orchestrate awe-inspiring experiences. Hosting a major, signature track and field event was central to the vision that Lananna and other leaders held for kick-starting the resurrection. One interviewee explained, "If you're going to aspire to raising the bar and doing something fantastic, the Olympic Trials really sets that stage," adding "that's the pinnacle, that's the biggest and best event that you can host."

Myriad tangible and intangible resources were leveraged to stage this event and others that followed. Interviewees reported that in addition to recruiting professional athletes to run for postcollegiate teams such as the OTC Elite, the new coach recognized the need to rebuild the core, the UO track and field program. Noting the importance of marshaling talent that met the community's expectations, one observed, "The track program not only needed to be champions, but to deliver a product and engage the community." Another interviewee, remarking on the need to continue updating the physical resource of Hayward Field "just to keep it alive and improving," also noted the importance of finding new "icons" of the sport who could help rebuild an anemic relational system:

If Oregon is strong in track and field and cross country and you have a post-collegiate team like the OTC Elite that develops icons that the average fan can relate to, you know, [fans will] say I love Nick Symmonds, I have to go watch the kid run.

Between 2008 and 2010, Eugene hosted three major track meets (the U.S. professional and college national championships, and the Olympic Trials), showcasing inspiring performances and enabling community residents to connect to athletes. The performance of the UO teams began improving rapidly (bottom of Figure 3), and a number of athletes gained a devoted fan base. Renewed interest in the events and performances was evident in an upsurge in attendance at Hayward Field (top of Figure 3). An interviewee noted that attendance had "grown exponentially since 2005."

\section{Leadership Actions Tap and Rebuild Intangible Resources}

Unlike his predecessors, the new coach not only understood how to marshal tangible resources to produce orchestrated experiences, but also was cognizant of the centrality of symbols and relational systems to the identity. He noted, "I had been here before and seen such great events happen at Hayward Field. There is a difference between being a track fan at some other venue and being a fan at Hayward Field." Leveraging this unparalleled sense of place was critical to winning the bid to host the '08 Trials. One of Eugene's emissaries to the Olympic Trials Selection Committee recalled how evocatively the delegation's video had portrayed the wooden grandstands, the roar of the crowd, and historic performances at Hayward Field. After its showing, he said, “There wasn't a dry eye on the committee, because most of those people had competed at Hayward Field at one point in their life-and they knew exactly what we were selling."

In the run-up to the 2008 Trials and afterward, Lananna rebuilt connections to the community day-to-day. Before the start of track season, he hosted open community forums, "Tuesdays in Track Town," at which collegiate and postcollegiate athletes described their training progress and took questions. To accommodate growing crowds, in 2011 these events had to be moved to a larger venue. Lifting a page out of Bowerman's playbook, Lananna staged special events with star athletes, such as an attempt to set the American record in the rarely run $4 \times 1$-mile relay. He opened the gates to Hayward Field to all who wished to watch and invited fans down from the grandstands to circle the track, standing just meters from the athletes.

\section{Authenticating Orchestrated Experiences}

Much of this activity would have met with indifference had it not resonated with the Track Town that residents and custodians had known and loved. Some harbored doubts that the "very orchestrated and planned" efforts of the '08 Trials could recreate an identity that they knew had grown organically. Identity custodians who volunteered to work on writing the Trials' souvenir program took great care in crafting sections relating Eugene's history, saluting athletes, rhapsodizing about heroic performances, and celebrating Hayward Field itself. One noted she felt offended by newcomers trumpeting "Track Town U.S.A. forever" as a slogan, adding "it actually degrades it if you flaunt it." Another said he felt offended by the label embla- 
zoned upon the new "jumbotron" video scoreboard "because it reads, 'Historic Hayward Field,' and if you are that, you don't have to say that!"

Experiencing the actual Trials, however, laid these concerns to rest. Many interviewees remarked that the Trials had a grassroots ambiance, despite their expanded scale and extravagance. Local ecological groups self-organized to ensure that "Eugene '08" would become the first "green" Olympic Trials. Overwhelmed by residents seeking to volunteer for the Trials, the software designed to enroll them crashed. One long-time resident spoke of how Eugene had "wrap[ped] its arms around the event," adding "I can be pretty cynical, but I was just blown away by how the town came together ... everybody, even if they weren't a big track fan, found some way to connect." Another observed that residents had been "just waiting for this rebirth, and the Olympic Trials galvanized it." One, recalling the 1970 s, said

There was electric energy in the air back then and you're starting to feel some of that again. ... You can't completely compare it, it's a different time, it's a different era. ... . But can Eugene become Track Town again? Absolutely—and I think it's happening!

Indeed, many performances elicited exactly the same emotional response from the crowds that track fans recalled from the 1960s and 70s. One was sparked at the 2008 Trials in the men's 800-meter race, run on a warm July 4th evening in front of packed grandstands with an overflow crowd watching on giant flatscreens in the adjacent free admission festival area. In the final seconds, three runners from Oregon surged ahead to claim first, second, and third place, a finish that seemed inconceivable for most of the race. One long-time track fan reflected on this race: "There were a couple of races, one being the race with [UO runner] Andrew [Wheating], that gave me goose bumps because that's the way it was every time Pre ran." A newspaper account described the breathtaking finish as "the single loudest moment of any U.S. track meet. . . . A delirious crowd of 20,949 was on its feet, cheering so hard, and for so long, that the start of the next event ... was delayed for 15 minutes." Wheating, the runner-up, observed "If the Trials had been somewhere else, it would probably be like, 'Oh, here comes a guy on the outside. Nice job.' Kind of like a courtesy clap. . . . But here, it's more emotional. It goes a lot deeper" (Register Guard, 2009).

The 2008 Trials marked the start of a cascade of experiences that restored the aura of Track Town. A string of noteworthy meets were held in the years immediately following, generating experiences that enabled residents to connect, sometimes in new ways, to a remembered and symbolized past. Our brief structured interviews confirmed that Hayward Field, Steve Prefontaine, Bill Bowerman, and previous Olympic Trials remained among the most salient and celebrated identity referents at the time of the '08 Trials. One thing that enabled these past identity referents to remain relevant to contemporary residents and fans was the work of custodians who had, even when the identity was most under threat, crafted ongoing experiences that tapped these symbols. For example, the weekly All-Comers Meets, started by Bowerman in 1949, were still held every summer, with volunteers coming out year after year. One interviewee said, "Janet's there handing out those ribbons to the kids-and she's been doing it for 30 years." When the 2008 Trials attracted a surge of attention, these custodians seized the opportunity to reconnect venerable symbols to new grassroots efforts and connect new generations with the past. For example, All-Comers Meets were scheduled on the noncompetition "rest" days in the middle of the Trials, and each child competing received a T-shirt with a big red stop sign on the front imprinted with "STOP ME," an ironic reference to the "STOP PRE" T-shirts that Steve Prefontaine's fans had sported during the 1972 Olympic Trials. Later, when Lananna spread word that two local athletes would run a free, public "tune-up" race at Hayward shortly before departing for the Beijing Olympics, children packed the stands and then spilled out on the field to have the athletes autograph their "STOP ME" T-shirts and other memorabilia.

\section{Regenerating Intangible Resources}

Although these experiences were necessarily different from those enjoyed by prior generations of residents and fans, they authentically brought forward the symbolic resources that had contributed to Track Town's past identity, renewing and rebuilding the relational system upon which it drew. Importantly, the experiences did not simply reference past symbols; they literally recreated symbols in the form of memories and accounts laid down through experiencing and feeling. A local reporter who had covered UO track and field since Bowerman coached captured this when he spoke of the much-lauded 800-meter race at the 2008 Trials, noting that a lot of residents had been running on "borrowed memories":

The truth is, a lot of them didn't actually see Pre run in 1972, or see McChesney fall to his knees to kiss the track in 1982. But when we saw those three 
Oregon men sweep [the $800 \mathrm{~m}$ ] in 2008, well, that's our memory now.

Authentication also rewove the intangible resource embodied in the relational fabric connecting residents, fan, and athletes. One interviewee noted that the '08 Trials "helped to create a new set of fans in Eugene." The OTC enjoyed an upsurge in membership, with one interviewee noting that the organization "had waxed and waned over the years [but it has] really come back strong now." Echoing many interviewees' impressions that the timing was "just right" for reengaging identity custodians and ensuring they enrolled new ones, one organizer explained, "I think that people [from] that era were waiting to be asked. And once they were asked, they grasped it and passed it off to the next person . . . almost like a tree that flourished."

The Trials not only reenergized and recruited individual custodians, but seemed to endow the whole community with confidence in its ability to be Track Town again. One interviewee observed, "There was a sense of pride. People said, 'Wow, Eugene did something really great last summer and we can do it again!'” The upsurge of community engagement took all our informants by surprise, highlighting the resilience of a relational system that is energized by shared experiences, not simply drawn together by charismatic leadership. One organizer spoke of the emotional commitment that accompanied this engagement, saying "I can relate lots of stories about people brought to tears . . . volunteers who were so emotionally involved ... they were affected in ways that none of us ever counted on."

In 2009, the executive director of U.S.A Track and Field, the sport's governing body, was quoted in the newspaper as having committed to a "continuing partnership" with local organizers because "there's a magic that occurs when [Eugene] has a major event." He continued by depicting Eugene's identity not as a set of labels or claims but as feelings inseparable from place:

This is a cathedral for our sport. This is a temple for the sport. There is probably nowhere else in the country where you can get the same feel, . . . and I say this in a very positive way-there are ghosts here. There are ghosts that seep out of not only the venue and the institution, but ... [out of] what's occurred here.

As depicted in Figures 1 and 2, this shared sense of experience and emotion is critical to authentication, which, more than any other mechanism, acts to enable (or block) the regeneration of tangible and intangible resources required to perpetuate or resurrect a community identity.

\section{DISCUSSION}

Beginning with the puzzle of how actors resurrect a dormant collective identity, we uncovered a set of mechanisms for identity reproduction that, even when eroded, can be restarted by actions that energize identity custodians, elicit authentic experiences, and recreate cherished memories. In line with recent organizational accounts (Gioia et al., 2010; Ravasi \& Schultz, 2006), our findings suggest that perpetuating a collective identity is an ongoing accomplishment dependent upon the actions of leaders and members. Our model differs from these other accounts by explicitly describing mechanisms for resurrection following decline and by placing experience and emotion at the center of a processual understanding of identity. Here we elaborate on these contributions and discuss how our findings inform understanding of identity reproduction and resurrection in other settings. To map the boundaries of our theory, we note organizational settings to which it is best suited. Finally, we explore implications of our analysis for understanding interactions between communities and the organizations lying within them.

\section{Processes of Identity Reproduction and Resurrection}

Our model explains how a collective identity can be reproduced through recursive interactions between tangible resources (financial, human, and physical resources), intangible resources (symbols and relational systems), and experiences that are generated when leaders and members leverage these resources. Our model resembles the processual account that locates organizational identity in the interaction of claims and understandings derived, respectively, from the cognitive mechanisms of leader sensegiving and member sensemaking (Gioia et al., 2010; Ravasi \& Schultz, 2006). Identity claims and understandings can generate an "embedded dynamic" when leaders' claims influence member understandings, and vice versa (Ravasi \& Schultz, 2006). In our model, leaders marshal tangible resources (and astute ones also tap intangible resources) to orchestrate experiences. A similar embedded dynamic occurs when custodians and members, who are primed by prior experiences, evaluate these experiences as authentic.

This embedded dynamic can break down in several ways. As we found, when leaders slow the delivery of orchestrated experiences, identity decline can set in, even though members judge these experiences as authentic and resonant with the 
past. A different outcome, identity threat, begins when leaders fail to deliver orchestrated experiences of the caliber that have come to be seen as hallmarks of the identity. More threatening still is a leader's denigration of the intangible resources, particularly cherished symbols and relationships, which fuel ongoing identity-relevant experiences. In our case, it was a direct threat to the collective identity, not simply a decline or drift, that triggered renewal efforts. Future research could explore whether a threat is needed to catalyze to identity resurrection, or whether it might be triggered in other ways. In the case of Apple, the return of a visionary founding leader appeared sufficient to set resurrection in motion.

Restarting the identity reproduction processidentity resurrection-occurs when a leader can tap tangible resources to stage bold and appealing orchestrated experiences, updating while still epitomizing ones that came before. Such experiences act as brash attention-getters; the ads Apple artfully designed to cause employees to compare themselves to innovators like Edison and Gandhi are exemplary. Even so, such efforts may fall flat unless they are instigated by savvy leaders who command intangible identity resources and whose efforts are embraced by custodians and others who long to see their identity renewed. Molotch and his coauthors commented on efforts to regenerate community identities that rely on leader vision alone:

Getting wind of the possibility that local ambiance has something to do with creating "miracles" like Silicon Valley ... various governmental and civic agencies have intensified their efforts to alter the texture and trajectory of places. ... Plopping in a new museum, science park, or stadium ... all carry the risk of artificiality. Without the needed complementary elements in place, they may not be viable interventions. (2000: 817-818)

Our model of identity resurrection points to at least two elements that "complement" leaderdriven orchestrated experiences. First, effective leaders complement their mobilization of tangible resources by tapping intangible aspects of identity, activating its symbolic and relational elements. In this way, leaders also act as identity custodians who are the guardians of these intangibles. Second, the traces of an identity must have been maintained by custodians who have longevity in a collective. Beyond being the narrators of stories, or safeguarding records or mementos, these custodians must have continued to live (and offer for other members) the ongoing experiences that contribute to identity reproduction. Future research could ex- plore how the identity resurrection process unfolds in other settings. How do leaders' prior experiences within or outside a collective shape their efforts to marshal resources and direct these toward identity resurrection? What actions can custodians take to sustain an identity through periods of decline? Does, and how does, custodianship differ across settings? Recent work on how members sustain a collective identity and even bring forth new organizations following the extreme case of organizational death (Walsh \& Bartunek, 2011; Walsh \& Glynn, 2008), suggests that custodians may be crucial in organizational settings too.

\section{Experience and Emotion in Identity Processes}

Our perspective differs from that in prior work on identity processes because it foregrounds experience over cognition as the engine driving the reproduction and resurrection of a collective identity. Lived experience, participation, and elicited emotions may be more potent than talk and ideas, at least in some settings, in conveying and reproducing an identity. Although scholars have long noted that identity has an emotional as well as cognitive component (Fiol \& O’Connor, 2002; Harquail, 1998; Tajfel \& Turner, 1979), the emotional and experiential aspects of identity are undertheorized and almost unstudied. Many studies of organizational identity limit their focus to members' "verbal descriptions of the organization's characteristics" (Harquail \& Wilcox King, 2010: 1621), but an expanded understanding would also embrace "what [members] can substantiate in their embodied experience" (ibid.: 1620). When scholars do attend to emotion and collective identity, they see emotional reactions as triggered by identity understandings, rather than seeing emotion as constructing identity understandings. For example, when threatened, group (Fiol, Pratt, \& O'Connor, 2009; Gutierrez, Howard-Grenville, \& Scully, 2010) and organizational (Dutton \& Dukerich, 1991; Elsbach \& Kramer, 1996) identities are said to elicit emotional reactions and arouse defensive mechanisms.

Our study suggests a more causal role for experience and emotional responses in propelling a collective identity because experiences and emotions did not merely reflect members' cognitive identity understandings, but, to a large degree, defined them. We do not deny the role of cognitive processes such as sensegiving and sensemaking in perpetuating identity, but we believe that members' experiences and emotional involvement can shape their identity understandings. This perspective echoes a recent call for treating sensemaking as potentially infused with emotion and for consider- 
ing how emotional intensity cues sensemaking episodes (Weick, Sutcliffe, \& Obstfeld, 2005). The intensity and valence (positive or negative) of emotional arousal can shape individual and group action, but interactions among emotion, sensemaking, and organizing processes are only beginning to be explored (Walsh \& Bartunek, 2011).

Attention to experience and emotion can contribute to understanding identity persistence, decline, and resurrection because they help explain how past identities are made meaningful to new generations of members and how symbols and other resources are literally regenerated to drive a present identity forward in time. First, experiences vividly connect participants to a symbolized and remembered past. Recent attention to the role of legacy, history, and tradition in organizational processes (Ravasi, Rindova, \& Stigliani, 2012; Schultz \& Hernes, 2010; Walsh \& Glynn, 2008) highlights the "power of the past." Our analysis suggests that the past is made powerful when actors, rather than treating symbols as passive carriers of meaning, actively engage in "manufacturing and reproducing traditions and heritage [that] are passed down through successive generations, providing the raw material for identity formation" (Weber \& Dacin, 2011: 294). We see identity custodians as guardians of the past who reproduce the ongoing, everyday experiences that enroll community members and help them to care about the identity. Unlike a "legacy identity" that survives the death of a firm but lives on in the "collective memories and activities" of former members (Walsh \& Glynn, 2008: 262), a collective identity reproduced through experiences survives generational turnover as it is experienced anew.

Second, experiences and emotions generate new memories and symbols to reload the "bank" of intangible resources available to be tapped. Sharing new experiences rebuilds the relational system that amalgamates individuals into a collective (Lampel \& Meyer, 2008). Glynn's account of changes in Atlanta's identity stemming from its hosting of the Olympic Games shows that such an event can introduce symbols that reshape relationships among elites (2008). Glynn noted that "events, particularly those that are visible public rituals and ceremonies, can serve up a ready-made set of beliefs" (2008: 1140). In contrast, the events and experiences in our case drove identity resurrection through their resonance with the past. Instead of introducing a new vision, they restored a relational system in need of repair. Our analysis suggests experiences will fall flat if they offer "ready-made" beliefs that custodians cannot judge authentic. Thus, experiences do not simply manufacture or coalesce iden- tity understandings in one-off fashion. Instead, a chain of linked experiences drives identity forward by evoking shared emotions, connecting participants to past, present, and expected future instantiations of the collective identity.

\section{Applying Our Model in Other Settings}

Although we developed our process model by studying the resurrection of a community identity, the mechanisms we uncovered have implications for scholars whose interests center on organizational identity processes. As noted above, introducing experience and emotion to a processual understanding of identity can complement cognitive mechanisms without replacing them. However, we do expect lived experience to play a larger role in identity processes in particular settings. These include business organizations whose identities and brands embrace culture and tradition. Scholars have noted that in certain companies, lived experience becomes so fundamental that it spills over from a company to foster a customer "brand community" (Fournier \& Lee, 2009). Harley-Davidson, the iconic American motorcycle manufacturer, perhaps illustrates this best. Following its near-death in 1983, Harley-Davidson orchestrated shared experiences that brought its employees, managers, and customers into direct contact. Employees responded to incentives to become Harley owners and riders, led weekly rides, and hosted rallies for their customers (Fournier \& Lee, 2009). Although Harley's public relations professionals supplemented these ongoing experiences with carefully crafted claims tapping into the mystique of the "hog," what we term "ongoing grassroots experiences" clearly played a central role in the firm's resurrection. An informant in our own study related a story that further demonstrates the role of experience in reproducing an organizational identity. Nike, the firm that grew from Bill Bowerman's experimentation with lightweight running shoes at Hayward Field, continues to socialize management trainees by bussing them to Hayward Field from corporate headquarters-to sit silently in the East Grandstand, and "soak in the ether of how Nike began."

Even without a strong brand, organizations that take a long view may invoke custodianship, experience, emotion, and authenticity as mechanisms to perpetuate or renew their identities. Voluntary organizations, which recruit and retain members on the basis of shared values and visions, rather than as part of a wage bargain, are especially well suited to using orchestrated experience and elicited emotion to keep the organizations' identities strong and up-to-date. Long-lived business organizations also 
confront the need to periodically refurbish timeworn "assumptions and beliefs underpinning the collective sense of self" (Ravasi \& Schultz, 2006: 451). Some organizations access their past primarily through stabilized forms, such as artifacts in company museums, logos, or former mission statements (Ravasi et al., 2011; Schultz \& Hernes, 2010; Walsh \& Glynn, 2008), but recent calls for greater attention to "living memory," as opposed to simply "textual memory" or "material memory" in shaping organizational identity (Schultz \& Hernes, 2010) suggest that probing experiences and emotional responses may prove fruitful in understanding how identity is reproduced or resurrected in such settings.

Experience and emotion may be less relevant to identity processes in other types of organizations. Companies commercializing rapidly evolving technologies or pursuing emerging markets may opt to sever ties to the past and link their identities to contemporary developments. In some companies, leaders invoke "simplified reconstruction[s] of an alleged past" (Ravasi \& Schultz, 2006: 453) to create a sense of continuity in the face of change (Gioia et al., 2000), or selectively connect aspects of a past identity to aspects of a present-day identity seen as desirable to outsiders (Chreim, 2005). Such moves may be tolerated or even endorsed in high-velocity environments where members value keeping up with trends and matching outsiders' evolving expectations. Such companies are more likely to pursue socially validated identity categories than to claim an idiosyncratic tradition or brand, suggesting boundary conditions for the application of our model of identity reproduction and resurrection.

\section{Interactions between Community Identity and Organizational Identity and Action}

Finally, our study points to ways of furthering understanding of how organizational identities and actions are shaped by the identities of the geographically emplaced communities in which they reside. In the organizational literature, attention to community has often focused on how the geographical colocation of organizations creates knowledge spillovers that influence the prospects of individual firms (Freeman \& Audia, 2006; Romanelli \& Khessina, 2005). Community identity in these works can refer simply to labels that companies and others use to talk about a particular region (e.g., Silicon Valley). Yet community can be conceptualized as more than a locale for situating organizations, having been defined as a composite of:

The populations, organizations, and markets located in a geographic territory and sharing, as a result of their common location, elements of local culture, norms, identity, and laws. (Marquis \& Battilana, 2009: 286)

With this emphasis, work on organizations and communities shifts from a focus on economic spillover to addressing how social structure perpetuates shared norms (Glynn, 2008; Marquis, 2003). Still missing is attention to how members experience and develop meanings associated with community (Marquis \& Battilana, 2009). Even sociological studies of community have been critiqued for excessive focus on social structure, power relations, and demographic factors, overlooking the possibility that "ideas, culture and identity matter at least as much as social structure for the development of particular forms of social interaction" (Vaisey, 2007: 854).

Our study shows that community identity can be vividly experienced and felt, and that organizational elites are but one contributor to its reproduction. Organizations also play a role in perpetuating the experiences and harboring the symbols that drive a community identity forward. Though studying the role of organizations in the current setting was beyond the scope of our study, we identified them as including the University of Oregon, the city and county governments, the Oregon Track Club, and Nike. These organizations' identities intertwine with those of the communities in which they reside or originate. The implication is that, like Chinese boxes, identities are "nested." A work group, department, organization, and community may share aspects of identity (Ashforth, Harrison, \& Corley, 2008), and the degree to which these identities interleave shapes identity content and fluidity (Gioia et al., 2010).

Can a community identity and an organizational identity cue each other and generate reciprocal actions that reinforce and coproduce identity? For which kinds of organizations might this be particularly appropriate or useful? Cross-level coproduction seems particularly likely to benefit organizations located in places with a strong regional identity (e.g., Branson, Missouri [see Chiles et al., 2004]), or organizations such as hospitals or universities that incorporate clients in the production of a service (and hence serve colocated community members). Future work could explore how colocation generates and sustains experiences, meanings, and emotional responses that drive interactions among individuals, organizations, and their communities. An informant in our study who worked for the county visitors bureau confessed that playing a part in Track Town's resurrection had made her feel better about herself-“I'm more confident and optimistic now." The possibility that individ- 
ual, organizational, and community identities might be cocreated opens up a fruitful direction for further research.

\section{Implications for Process Research}

Our work highlights new directions for process research and process thinking (Langley, 2007). First, it encourages organizational scholars to recognize experience and emotion as potential triggers and drivers of process and to use methods that enable them to observe and experience these factors. Much process research has focused on action, and much relies heavily on ethnographic methods garnering data from observation and participation, yet most researchers analyze process data primarily in cognitive or linguistic terms. Proponents of process research have challenged scholars to "plunge deeply" into process, rather than skim the surface (Langley, 1999), and we call for deep dives that theorize and measure experiences and emotions. Our research was facilitated greatly by the opportunity to interview lifelong members of the community who could vividly recall "how it felt" even though decades had passed. We also benefited from viewing video clips, photographic images, and media accounts that captured some of the emotional tenor of past events.

Finally, our findings show that understanding some processes demands close attention to the actions and experiences of members, not just managers. Members, particularly custodians, were indispensible participants in maintaining Track Town's identity and in triggering and enabling its resurrection. Although powerful individuals from political, social, and managerial elites also drive processes, researchers have been "reluctant to query managerial agency" (Johnson, Langley, Melin, \& Whittington, 2007: 12), perhaps giving managers undue credit for outcomes. This may be especially true for processes of maintenance that transpire over very long time periods. In such cases, process researchers need to find and attend to the work of the custodians, storytellers, and shamans who bind the past, present, and future.

\section{REFERENCES}

Albert, S., Ashforth, B. E., \& Dutton, J. E. 2000. Organizational identity and identification: Charting new waters and building new bridges. Academy of Management Review, 25: 13-17.

Albert, S., \& Whetten, D. A. 1985. Organizational identity. In L. L. Cummings \& B. M. Staw (Eds.), Research in organizational behavior, vol. 7: 263-295. Greenwich, CT: JAI.
Ashforth, B. E., Harrison, S. H., \& Corley, K. G. 2008. Identification in organizations: An examination of four fundamental questions. Journal of Management, 34: 325-374.

Ashforth, B. E., \& Mael, F. A. 1996. Organizational identity and strategy as a context for the individual. In J. A. C. Baum \& J. E. Dutton (Eds.), Advances in strategic management, vol. 13: 19-64. Greenwich, CT: JAI.

Birnholtz, J. P., Cohen, M. D., \& Hoch, S. V. 2007. Organizational character: On the regeneration of camp poplar grove. Organization Science, 18: 315-332.

Brehm, J. M., Eisenhauer, B. W., \& Krannich, R. S. 2006. Community attachments as predictors of local environmental concern. American Behavioral Scientist, 50: 142-165.

Chambers Productions. 1995. Fire on the track: The Steve Prefontaine story (dir., Lyttle Erich; writ., Kesey Ken, Lyttle Erich, \& Moore Kenny). Eugene: Chambers Productions.

Chiles, T., Meyer, A. D., \& Hench, T. J. 2004. Organizational emergence: The origin and transformation of Branson, Missouri's musical theaters. Organization Science, 15: 499-519.

Chreim, S. 2005. The continuity-change duality in narrative texts of organizational identity. Journal of Management Studies, 42: 567-593.

Corley, K. G., \& Gioia, D. A. 2004. Identity ambiguity and change in the wake of a corporate spin-off. Administrative Science Quarterly, 49: 173-208.

Cowen, A. P., \& Cowen, S. S. 2010. Rediscovering communities: Lessons from the Hurricane Katrina crisis. Journal of Management Inquiry, 19(2): 117-125.

Dacin, M. T., \& Dacin, P. A. 2008. Traditions as institutionalized practice: Implications for deinstitutionalization. In R. Greenwood, C. Oliver, R. Suddaby, \& K. Sahlin-Andersson (Eds.), SAGE handbook of organizational institutionalism: 327-351. Thousand Oaks, CA: Sage.

Dutton, J. E., \& Dukerich, J. M. 1991. Keeping an eye on the mirror: Image and identity in organizational adaptation. Academy of Management Journal, 34: 517-554.

Eisenhardt, K. M. 1989. Building theories from case study research. Academy of Management Review, 14: 532-550.

Elsbach, K. D., \& Kramer, R. M. 1996. Members' responses to organizational identity threats: Encountering and countering the Business Week rankings. Administrative Science Quarterly, 41: 442-476.

Feldman, M. S. 2004. Resources in emerging structures and processes of change. Organization Science, 15: 295-309. 
Fiol, C. M. 2002. Capitalizing on paradox: The role of language in transforming organizational identities. Organization Science, 13: 653-666.

Fiol, C. M., \& O’Connor, E. J. 2002. When hot and cold collide in radical change processes: Lessons from community development. Organization Science, 13: 532-546.

Fiol, C. M., Pratt, M. G., \& O’Connor, E. J. 2009. Managing intractable identity conflicts. Academy of Management Review, 34: 32-55.

Flaherty, J., \& Brown, R. B. 2010. A multilevel systemic model of community attachment: Assessing the relative importance of the community and individual levels. American Journal of Sociology, 116: 503542.

Foreman, P., \& Parent, M. M. 2008. The process of organizational identity construction in iterative organizations. Corporate Reputation Review, 11(fall): 222244.

Fournier, S., \& Lee, L. 2009. Getting brand communities right. Harvard Business Review, 87(4): 105-111.

Freeman, J. H., \& Audia, P. G. 2006. Community ecology and the sociology of organizations. In K. S. Cook \& D. S. Massey (Eds.), Annual review of sociology, vol. 32: 145-169. Palo Alto, CA: Annual Reviews.

Galaskiewicz, J. 1997. An urban grants economy revisited: Corporate charitable contributions in the Twin Cities, 1979-81, 1987-89. Administrative Science Quarterly, 42: 445-471.

Gieryn, T. F. 2000. A space for place in sociology. In K. Cook \& J. Hagen (Eds.), Annual review of sociology, vol. 26: 463-496. Palo Alto, CA: Annual Reviews.

Gioia, D. A., Price, K. N., Hamilton, A. L., \& Thomas, J. B. 2010. Forging an identity: An insider-outsider study of processes involved in the formation of organizational identity. Administrative Science Quarterly, 55: $1-46$.

Gioia, D. A., Schultz, M., \& Corley, K. G. 2000. Organizational identity, image and adaptive instability. Academy of Management Review, 25: 63-82.

Glaser, B. G., \& Strauss, A. L. 1967. The discovery of grounded theory. New York: Aldine.

Glynn, M. A. 2008. Configuring the field of play: How hosting the Olympic Games impacts civic community. Journal of Management Studies, 45: 1117-1146.

Gutierrez, B., Howard-Grenville, J., \& Scully, M. 2010. The faithful rise up: Split identification and an unlikely change effort. Academy of Management Journal, 53: 673-699.

Harquail, C. V. 1998. Organizational identification and the "whole person": Integrating affect, behavior, and cognition In D. A. Whetten \& P. C. Godfrey (Eds.), Identity in organizations: Building theory through conversations: 223-231. Thousand Oaks, CA: Sage.
Harquail, C. V., \& Wilcox King, A. 2010. Construing organizational identity: The role of embodied cognition. Organization Studies, 31: 1619-1648.

Hollister, G. 2008. Out of nowhere: The inside story of how Nike marketed the culture of running. New York: Meyer \& Meyer Sport.

Hsu, G., \& Hannan, M. T. 2005. Identities, genres, and organizational forms. Organization Science, 16: $474-490$.

Jobs, S. 1991. Voices of innovation: Steve Jobs. Business Week, October 10. http://www.businessweek. com/stories/2004-10-10/voices-of-innovation-stevejobs.

Johnson, G., Langley, A., Melin, L., \& Whittington, R. 2007. Strategy as practice: Research directions and resources. Cambridge, U.K.: Cambridge University Press.

King, B. G., Felin, T., \& Whetten, D. A. 2010. Finding the organization in organizational theory: A meta-theory of the organization as a social actor. Organization Science, 21: 290-305.

Lampel, J., \& Meyer, A. D. 2008. Field-configuring events as structuring mechanisms: How conferences, ceremonies, and trade shows constitute new technologies, industries, and markets. Journal of Management Studies, 45: 1025-1035.

Langley, A. 1999. Strategies for theorizing from process data. Academy of Management Review, 24: 691710 .

Langley, A. 2007. Process thinking in strategic organization. Strategic Organization, 5: 271-282.

Locke, K., Golden-Biddle, K., \& Feldman, M. S. 2008. Making doubt generative: Rethinking the role of doubt in the research process. Organization Science, 19: 907-918.

Marquis, C. 2003. The pressure of the past: Network imprinting in intercorporate communities. Administrative Science Quarterly, 48: 655-689.

Marquis, C., \& Battilana, J. 2009. Acting globally but thinking locally? The enduring influence of local communities on organizations. In B. Staw \& A. Brief (Eds.), Research in organizational behavior, vol. 29: 283-302. Bingley, U.K.: Emerald.

Marquis, C., \& Davis, G. F. 2008. Organizational mechanisms underlying positive community identity and reputation. In L. M. Roberts \& J. E. Dutton (Eds.), Exploring positive identities and organizations: Building a theoretical and research foundation: 461-478. New York: Taylor \& Francis.

Marquis, C., Glynn, M. A., \& Davis, G. F. 2007. Community isomorphism and corporate social action. Academy of Management Review, 32: 925-945.

McDonald, S. B. 2009. Trading on Track Town. Register 
Guard, May 24. http://projects.registerguard.com/ csp/cms/sites/web/business/14032848-46/story.csp.

Meyer, A. D. 1991. Visual data in organizational research. Organization Science, 2: 218-236.

Miles, M. B., \& Huberman, M. 1994. Qualitative data analysis: An expanded sourcebook. Thousand Oaks, CA: Sage.

Molotch, H., Freudenburg, W., \& Paulsen, K. E. 2000. History repeats itself, but how? City character, urban tradition and the accomplishment of place. American Sociological Review, 65: 791-823.

Moore, K. 2006. Bowerman and the men of Oregon: The story of Oregon's legendary coach and Nike's cofounder. Emmaus, PA: Rodale.

Oregon Public Broadcasting. 2011. Oregon experience. Portland: Oregon Public Broadcasting.

Ravasi, D., \& Phillips, N. 2011. Strategies of alignment: Organizational identity management and strategic change at Bang \& Olufsen. Strategic Organization, 9: 103-135.

Ravasi, D., Rindova, V., \& Stigliani, I. 2012. The stuff of legend: Mnemonic practices and the construction of organizational identity in corporate museums. Working paper, Bocconi University.

Ravasi, D., \& Schultz, M. 2006. Responding to organizational identity threats: Exploring the role of organizational culture. Academy of Management Journal, 49: 433-458.

Reger, R. K., Gustafson, L. T., Demarie, S. M., \& Mullane, J. V. 1994. Reframing the organization: Why implementing total quality is easier said than done. Academy of Management Review, 19: 565-584.

Romanelli, E., \& Khessina, O. M. 2005. Regional industrial identity: Cluster configurations and economic development. Organization Science, 16: 344-358.

Saxenian, A. L. 1996. Regional advantage: Culture and competition in Silicon Valley and route 128. Cambridge, MA: Harvard University Press.

Schultz, M., \& Hernes, T. 2010. Powers of the past: Evoking organizational memory in identity reconstruction. Academy of Management best papers proceedings: $1-6$.

Scott, W. R. 2003. Institutional carriers: Reviewing modes of transporting ideas over time and space and considering their consequence. Industrial and Corporate Change, 12: 879-894.

Sewell, W. H.. Jr.. 1992. A theory of structure: Duality, agency, and transformation. American Journal of Sociology, 98: 1-29.

Tajfel, H., \& Turner, J. C. 1979. An integrative theory of intergroup conflict. In W. G. Austin \& S. Worchel (Eds.), The social psychology of intergroup relations: 33-47. Monterey, CA: Brooks/Cole.
Tripsas, M. 2009. Technology, identity, and inertia through the lens of "The Digital Photography Company.” Organization Science, 20: 441-460.

Vaisey, S. 2007. Structure, culture, and community: The search for belonging in 50 urban communes. American Sociological Review, 72: 851-873.

Walsh, I. J., \& Bartunek, J. M. 2011. Cheating the fates: Organizational foundings in the wake of demise. Academy of Management Journal, 54: 1017-1044.

Walsh, I. J., \& Glynn, M. A. 2008. The way we were: Legacy organizational identity and the role of leadership. Corporate Reputation Review, 11(3): 262-276.

Weber, K., \& Dacin, T. 2011. The cultural construction of organizational life. Organization Science, 22: 286298.

Weick, K. E., Sutcliffe, K. M., \& Obstfeld, D. 2005. Organizing and the process of sensemaking. Organization Science, 16: 409-421.

Whetten, D. A. 2006. Albert and Whetten revisited: Strengthening the concept of organizational identity. Journal of Management Inquiry, 15: 219-234.

Whetten, D. A., Felin, T., \& King, B. G. 2009. The practice of theory borrowing in organizational studies: Current issues and future directions. Journal of Management, 35: 537-563.

Whetten, D. A., \& Mackey, A. 2002. A social actor conception of organizational identity and its implications for the study of organizational reputation. Business $\mathcal{E}$ Society, 41: 393-341. MA

Jennifer Howard-Grenville (jhg@uoregon.edu) is an associate professor of management at the University of Oregon's Lundquist College of Business. She received her Ph.D. at MIT. She uses qualitative methods to study processes of change in organizational and other settings, building theory on routines, issue selling, culture, and identity.

Matthew L. Metzger (mmetzger@uccs.edu) is an assistant professor of entrepreneurship and innovation at the University of Colorado, Colorado Springs. He received his Ph.D. from the University of Oregon. His research investigates the dynamics of organizational identity, with a particular emphasis on identities in nascent and rapidly changing organizational categories.

Alan D. Meyer (ameyer@uoregon.edu) is the Charles H. Lundquist Professor Emeritus of Management at the University of Oregon. He received his Ph.D. in organizational behavior and industrial relations from the University of California, Berkeley. He is a field researcher who uses organizational theory and sociology as theoretical frames to study corporate venturing, university entrepreneurship, technology commercialization, institutional change, and industry evolution. 